\title{
The Consumer's Behavior in the Arms of Semiotics: New Revelations
}

\author{
Karima Amirat \\ Faculty of Economic Science and Management of Tunis, Tunis, Tunisia
}

\begin{abstract}
We all know that buying a car is an act of consumption under constraint. It is subjected to a process of identical co-construction joining a socioeconomic context in perpetual transformation. This looks a little bit hard to understand! But the semiotic analysis of 28 interviews realized with the Tunisian executives, between 30 and 35 years old, about the brand of their personal cars, will simplify it by revealing us the values of consumption, the underlying signs in the various brands, the process of identical construction which joins to it and the implications that can appear on the consumer and the contemporary marketer there.
\end{abstract}

Keywords: identity, semiotics, consumer, values.

\section{Introduction}

Nowadays, the marketing strategy does not put more on the invention of one or several advantages for the product but it draws its strength essentially of how to assert them. This development is subjected, certainly, to codes and standards pre-established which facilitate the perception and the understanding of messages by the ordinary consumer. Some publications handling this subject, present certain interesting elements, such as those of Venkatesh, Alladi ( 1999 ) and Venkatesh Alladi and Firat A.Fuat (on 1993; on 1995) stipulating that to be able to stay in this universe of creation and anticipation, the marketing always has to try to break, to innovate, and even to create codes personalized for every brand. This, will arouse the attention, the implication and even the embodiment of the values uttered by the consumer (Heilbronn Benoit, on 2005), transformed into a consom-actor because it is him, henceforth, who acts on the message and not the opposite.

On the other way, it is evident that the notion of the brand in marketing is subjected to a system of registers. These registers are in perpetual transformation according to the spatiotemporal frames which emerge them (Holt, on 2002). So, the marketing research must know how to adapt itself to the new horizons which exceed the threshold of communicational maturity which reached the contemporary society (Bruno Jarrosson, on 2004). The creation is not any more congealed at the level of the invention but it undergoes in the impulse of the innovation and even the premonition of its own credos and values which they convey.

This analysis leaves a problem trying to identify what kind of relation the consumer maintains with the product of not common consumption? And to reveal which degree of implication the contextual and sociocultural constraints have on this relation? So, this work postulates on the general hypothesis stipulating that the acquisition of a product of not common consumption is an act by which the consumer reproduces his interaction with the global context throughout the process of the construction of his personal identity. This act generally arises from a quest of peculiarity, of independence and of unique existential experience. 
To be made, our approach will articulate around two main shutters. The first one will be inspired by previous studies handling the values of consumption to interpret the comments of our referees in order to propose a general model of the consumption and the process of the identical construction as well as a semiotic mapping (or the semiotic square of Floch) values of consumption relative to the acquisition of a personal car. The second shutter will be dedicated to the interpretations and the implications towards the classic marketing approachs as for the approaches on the behavior of the consumer. We shall evoke that the dichotomy consumer-product should rather bet on a triangulation incorporating the notion of relation. The consumption is an act deriving from an arrangement with the discursive systems and concerning a complex process of identical construction.

\section{Method of the Semiotic Analysis}

According to the semi-directive maintenances that we made with a sample of 28 Tunisian executives, between 30 and 35 years old, working in the zone of big Tunis and following the guide of interview quoted in the appendix, we were able to collect a rather important avalanche of data. These data would have been able to be analyzed by following the classic methodology of analysis data going of the thematic analysis to the exploratory phase until the purification and the validation of the scales of measure and a model research. That will not be the itinerary followed in our case. In fact, as we mentioned it from the beginning, it is here about a semiotic analysis which will consider the comments held by our 28 referees as personal, subjective and heterogeneous narratives. Having said that, to reach an exhaustive analysis allowing elaborating an abstract model semiotically correct, we will, first, fix four axes of interpretation revealed by the previous studies concerning the theme of the contextualization of the values of consumption.

The first axis concerns the studies of Ricoeur (1990) who stipulates that the narrative of the life of a human being emanates from his own construction. This construction is the fruit of a personal interpretation of his position from the circumstances surrounding him. Nevertheless he specified the importance of the existence of a narrative model because of the evasive character which depicts our existence. That's why; the comments of each of our referees must be analyzed as singular narratives of several narrative identities.

During the maintenances we detected that the storyline follows a kind of chronological order presenting past events, present reports and future ambitions. In fact, by answering our question "Since when you possess your own car?" Many of our interviewees told us rather their old memories and anecdotes on their first experiences to drive "I drove even without license" (Khaled), "I often pricked the car of my father when I was at the high school to show off in front of the girls" (Zied). This distortion of the question did not bother us because we knew that the meaning wished by our question was transmitted.

In fact, to possess its own car is synonymic of the achievement of certain independence and personal or professional maturity. Our referees broke it in the fact of knowing how to drive which is an act that precedes by a few years the acquisition of its own car to show us that they reached this independence for a long time. The narrative in the present we detected it in the answers to the questions as "What evokes the word transport for you? ". Answers as "my car is my second wife" (Akram), "it is a present of my father" (Noura), "it is my toy I spoil it every day" (Imen) revealed us the relationships that our referees maintain with their cars which the acquisition is on no account a harmless act. More than a financial investment, a car is also an emotional and moral investment. "I shall have a big family car" (Afef), "I will buy the last one Ferrari on the market" (Nacer), "I shall keep mine, I am on good terms" (Noura). All these answers revealed us the peculiarities in the future ambitions of our referees. 
This peculiarity shows itself in the fact that Bajoit (2001) has conscript the tension between two life plans (succeed socially by the will appear or manage to give a sense to its life independently of the glance of the other one by the will be). Nowadays this tension is handled as the phenomenon of ' the self invention' as Coutant Alexandre ( 2009 ) describes it inspired by papers of Jean-Claude Kaufmann ( 2004 ), so to change its car is a future event standing out at our referee's, it is subjected to this tension except for the competition of the budgetary constraints.

As for the second axis we seize it in the works of Landowski (1997) for whom the construction of a singular identity can be made only further to what he calls the otherness. This means that only while comparing with others individual reaches a person would be able to encircle the features of his own story. This approach is of an important contribution for our subject because we are in fact in a quest of a socio-semiotic analysis which considers the social interaction governing the behavior and the value system of every interviewed referee. The same concept of social interaction was analyzed in more recent studies treating the influence of the social identity of companies on the behavior and the loyalty of the consumers (Longinos Matin, Salvador Ruiz, and Alicia Rubio, on 2009).

Indeed, answers as " how my car was an old convertible Golf when I was student, now I opted for a family popular car " ( Ramzi), " I don $t$ like anymore my Yaris I want a more elegant and attractive car" (Asma), " it is not because I have no means, but I do not try to possess a big sedan, I like the utilitarian cars and practice especially those whose parts are available on the Tunisian market, I do not judge people who have beautiful cars moreover in the district or I live in the majority of my neighbors has beautiful cars " (Walid), " the majority of my friends envy me for my Mini Cooper and that pleases me, it is so nice and distinguished" (Ines).

These answers highlight four strategies to become identified with regard to the other one through the acquisition of a car: the first is the one of membership (Bourdieu, on 1979) emanating from the fact that a car always has to reflect the civil, social and professional situation of his owner. The second is the one of demarcation stipulating that a car is a modern means to facilitate the movement for active peoples and those who succeeds in their lives. The third is the one of alignment, the utility of a car lives in its practical asset, and it is a simple means of transportation which choice must not be subjected to the sociocultural constraints. Finally, the fourth which is the one of peculiarity (Brewer, on 1991), to possess a car it is a means to distinguish itself with regard to its circle of acquaintances, and more the car is expensive and inaccessible more this distinction is made a success on the negative or positive direction of this distinction. In a more recent context Guy Parmentier and Sylvie Rolland (2009) underline that during the passage to the virtual world these four identical types of positioning will henceforth be identified as that the duplication, the improvement, the transformation and the metamorphosis.

Certeau (1980) put the finger on another shutter of this quest of peculiarity at the human being. In fact, we can distinguish ourselves and create our own story and our own identity only by the daily stereotypical misappropriation of the customs and the values imposed by the socio-cultural constraints. To divert includes the fact of undergoing but also of using its guile to succeed in appropriating a personal vision and an atypical behavior in front of received messages and of the constraints imposed without shocking its circle of acquaintances or striking the social value system. It is our third axis of analysis.

This intelligent misappropriation is appointed by Levi Strauss (1962) by the metaphor of the do-it-yourself in which a consumer is in fact a handyman who establishes a kind of dialogue with the established socio-cultural elements then he proceeds to an assembly shaped according to his own vision towards an intersubjective identical construction. It is simply a quest of differentiation on a 
bottom of resemblances. "I and all my colleagues at the work, except for the boss, we have the same car, Clio, but mine is different because I am a fan of the tuning. Practically every month I add the last creations in this domain " ( Ali), " I use my Peugeot 206 in the daytime of the week to go to the work, to return the children, to go shopping but for the weekend I have my $4 \mathrm{X} 4$ jeep it is my whooping cough I use it to make the rides between friends or to go to watch the farm of my parents, I know that this luxury is not given to everybody, even to me, I have of to make many concessions for the credit note, in fact I think that it was rather an obligation than a choice " ( Taieb), " my car is Megane, we quite have a soft spot for this brand of car in my family but mine I maintain it daily, I loathe dirty cars, it is a real Calvary you know, especially with the children " ( Zayneb).

All these answers reveal us that there are really no deep disparities between our referees especially on the social and economic plan but there are tinkered demarcations which allow each of them to be distinguished to the others.

The fourth axis is a combination between the works of Barthès (1957) and works of Douglas and Isherwood (1979). In reality, the first one evoked and criticized, to succeed in interpreting all the meanings emanating from such a type of behavior or from another, we have, firstly, to understand what he calls the notion of "myth" that are typical representative examples resulting from an archaic and motionless socio-cultural classification of the human behavior. In another shutter, Douglas and Isherwood considered that every individual is in fact his own myth. By his acts of consumption and the values which govern them, every consumer builds his own universe and his own meanings of which he is the only ambassador (Dickinson and Carsky, on 2005). The choice of a brand of car is not only subjected to the fact of filling the need to belong in a definite group; it is also a revealing act of an outfit of inter-subjective information on his tastes, family, career, village ...

" All the families possess a popular car, it is indispensable nowadays " ( Noura), " it is normal that we look all to have the last launched on the market car, later it is a question of financial means ", " the boss of my bank harasses me ceaselessly, he wants to convince me to apply for loan for the purchase of a new car, I do not know why he can $t$ understand in which point I like my current car, it accompanied me in all the stages of my life, I am not still ready to change it " (Hanen), " the day of my marriage I insisted to use my own car in spite of the critics of my close relations and my wife's family, in fact, this car was the place of our first kiss and we wanted that it attends the happy end that knew our love story " (Wassim).

All these answers testify of the omnipresence of the naivety in the consumption of the myths by our referees. It is there even in their reluctances through one supposed demythologization. All vacillate between the facts of to admit either to ignore the socio-cultural and economic factors which intervened in the act of acquisition of a personal car.

Nevertheless, all our referees stripped in a spontaneous way the outfit of the meanings connected with their cars. The approval or the disapproval of their circles of acquaintances was never a strong constraint to show a kind of sentimental attachment, semiotically very expressive, in their cars. The value of a car emanates not only from its social value and or price, but also especially from all the subjective meanings which it conveys through the memories and the personal experiences lived in its presence. The projection of the answers uttered by our referees allowed us to elaborate a semiotic model of the production of the identity through the acquisition of a new car which appears as follows: 


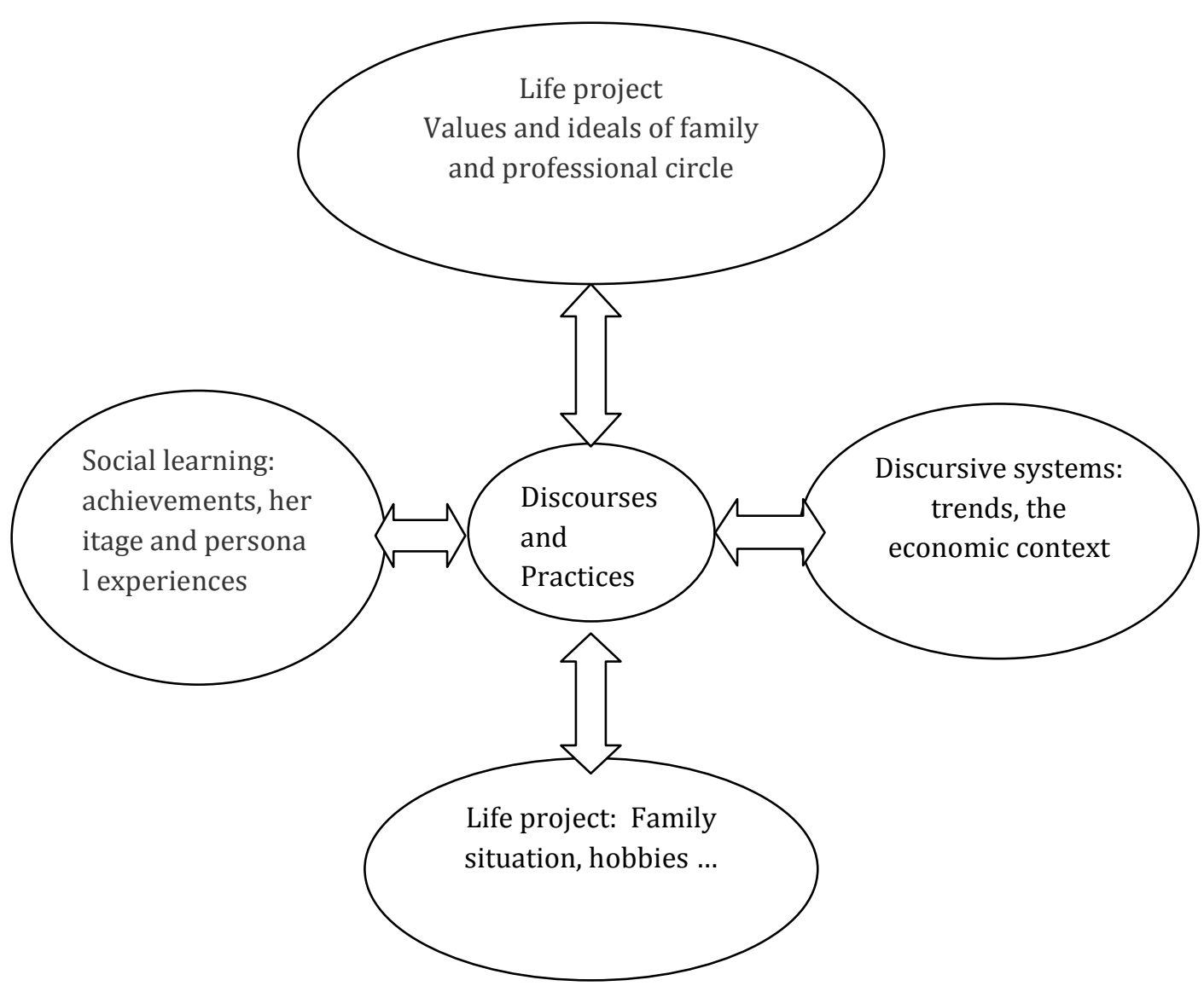

Fig 1. General Model of the Identity Construction of the Tunisian Frames through the Personal Act of a Car Acquisition.

The Semiotic Mapping of the Consumption Values in the Acquisition of a Personal Car

An avalanche of recent studies bent over the contribution of semiotics in the marketing generally such as those of Floch J. M, (2002), Fontanille J. ( 2003 ), Hébert L. ( 2006 ), Mick D.G ., Burroughs J.E ., Hetzel P., Brannen M.Y . (2004), Assassi, Isabelle; bud-Renault, Dominique (2010), JeanJacques Boutaud ( 2007 ) ... By the way, we can notice that rare are the ones which focused on a field, a domain and or a particular concept of the marketing such as it was place during the last and the front last decade. As examples we can quote some key studies which marked precise fields of reflection such as those of Christinsen, L.T., Askegaard, S. (2001), Semprini A. (1992) And Nicole EveraertDesmedt ( 1999 ) on the image and the identity of the brand and those of Dano, F. ( 1994 ) and Solomon, O. (1988) on the design and the packaging. But we can say that attempts of reconciliation of the semiotic analyses and studies on the consumers' perceptions (Nathalie Veg-Sala, on 2010, 2012) begin to extend again the marketing domain.

In this part of the analysis, we will focus on the works of Floch (1990). A study using the semiotic square as tool of analysis of the consumption process in hypermarkets, he was able to identify four types of attitudes among the consumers: the friendly, the consumerist, the exploited and the bargain hunter.

On the semiotic plan this analysis allowed to reveal that the behavior, the attitudes and the expectations revealed through the narratives of the referees, in spite of their 
disparities, can be classified according to limited axes of valuation. Floch (1990) bounded to them by throwing the opposition between the use values and the basic values on the semiotic square what allowed him to distinguish four virtual meanings positioning that he nominated the four axes of valuation:

- The axis of the practical valuation: indicates the virtual typology of the consumers who are interested in the use values such as features, solidity, utility...

- The axis of the critical valuation: indicates the virtual typology of the consumers who estimate constantly the product by subjecting it to a comparison and a judgment according to external criteria.

- Practicality

- Flexible and adaptable forms

- Respect environment

- Utility Options

- Dynamism
- The axis of the playful valuation: Indicates the virtual typology of the consumers who establish a close relationship with the product with a total indifference towards its materialist and tangible assets.

- The axis of the utopian valuation: indicates the virtual typology of the consumers who are in search of utopia through abstract or immaterial criteria of the product.

By applying the various performances uttered via the answers of our interviewees to these four semantic valuation axes, the semiotic mapping (or the semiotic square of Floch) values of consumption relative to the acquisition of a personal car would be as follows:

\section{Utopian}

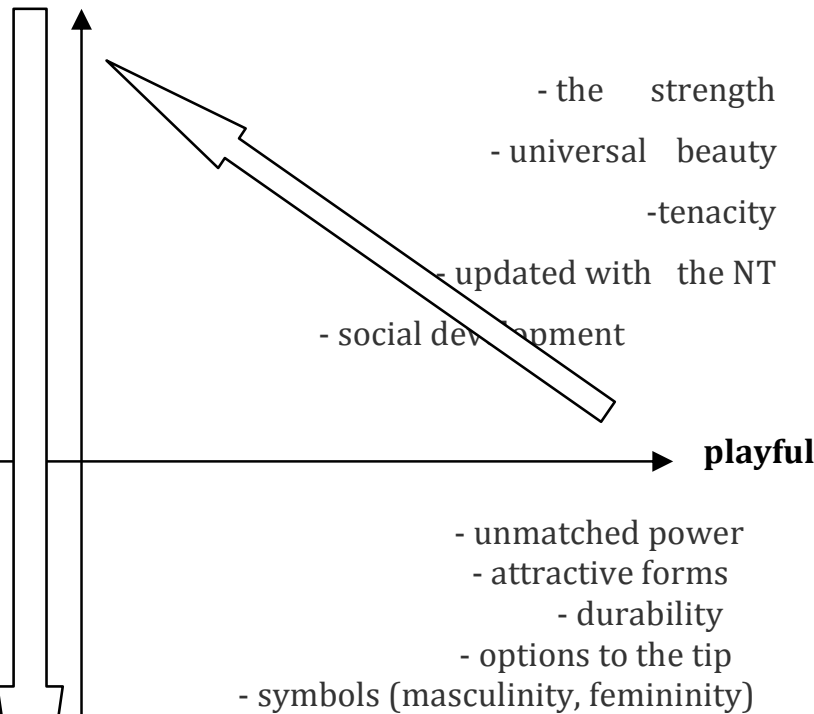

Standard image

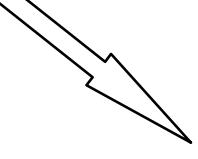

- unmatched power - durability - symbols (masculinity, femininity)

\section{Practice}

Fig 2. The Semiotic Mapping of the Consumption Values Relative to the Acquisition of a Personal Car. 
This semiotic mapping allowed me to propose five concepts allowing describing the values of meaning associated with the acquisition of a personal car:

- The robustness

- $\quad$ The aestheticism

- The stamina

- The technology

- The social image

The projection of these five concepts on the various axes of valuation will allow us to reveal the outfit of the values of the consumption and consequently the various motivations (hedonists, ablatives, of social image) which catalyze the process of a personal car acquisition.

- The Positioning of Utopian / Critical Direction: a personal car is the ideal solution to facilitate the mobility of employees especially in the urban zones, for that it must be practical and moldable and why not small-sized to facilitate the movement and the car park. From an aesthetic external point of view, the forms of the car's carcass must be not cumbersome to facilitate the travel especially in the rush hours. About stamina, the personal car must be easy to maintain what will extend its life expectancy and at the same time will insure the environmental protection.

A personal car of an active junior executive has to contain only the most utilitarian and most basic options to avoid the wasting in term of energy and concentration (a radio set, an air conditioner and a central lock, not need to be state-of-the-art), this concerns the axis of the technology. And finally, about the social image, all these assets which we have just attributed to the personal car will make of it a major consumer product reflecting a contemporary social image strongly looked for nowadays (be dynamic, in his ease at work and with circle of acquaintances, persevering, committed, serious).

\section{- The Positioning of Utopian / Playful} Direction: Under the axis of the robustness, a personal car must be solid to be able to resist in front of a daily use, generally in very active urban zones or the traffic jams and the collisions are frequent. About the aesthetics, the models and the designs of the personal cars intended for the junior executives are recognized all over the world and appreciated as modern popular cars. The axis stamina is shown by the number of visits at the mechanic, for the junior executives the investment in the purchase of a personal car is not a harmless act in their life plans, so more this car is firm and resistant more this investment remains profitable.

Between the playful and the utopian, the axis of the technology in this quadrant stipulates that a personal car must be hurried equipments of the new technologies, indeed the technology will only be perfecting and facilitating its functioning. The last axis of the social image reveals that the acquisition of a personal car is a means of social selffulfillment; it recovers from a kind of independence, it facilitates the life, it creates and strengthens social affinities in the professional and relational circle.

- The Positioning of Practical / Playful Direction: this virtual position is accommodated between the playful and practical so it is the position of the referees in search of perfection, of enjoyment by the pleasure to be swamped and satisfied by the assets of their car under the various handled axes. The robustness in this shutter is synonymic of unequalled power of the engine, the stability and the dominance on the road just like the very dynamic, ambitious and belligerent junior executive. The aestheticism is synonymic of attraction, demarcation by original and contemporary forms. The stamina is synonymic of longevity, in fact this beautiful, powerful and attractive car must know how to keep its charm as long as possible even if its model is exceeded by time, its retro style can do and tidies 
up it in the category of the perennially fashionable mythical cars.

The technology is synonymic of sophistication, more the options and equipments are state-of-the-art more the pleasure to drive this car is there. Finally the social image is synonymic of all the symbols and the meanings that this car can transmit. A woman junior executive wants her car just like her modern and audacious femininity; a junior executive wants it just like him at the same time innate and civilized virility.

\section{- The Positioning of Practice / Critical} Direction: the values conveyed in this position emanate from intrinsic assets of the car appearing without fetching in it beyond the meanings which it can transmit. A personal car must be judged or estimated according to its shock resistance and at the unforeseen of the road, this under the axis of the robustness. Under the axis of the aestheticism, the assessment criterion is the series number or the model reflecting the age, the performances and the state of its parts. The stamina is calculated by the life expectancy of the engine and the resistance of candles and also by other very technical and detailed criteria. The technological axis does not live in the fact of being equipped with a high technology but rather in the fact than the basic technology of this car is perfected and good mastered. The social image is not a dominating axis in this quadrant because the popular image is the one of a standard junior executive folded in the standards and in the socio-cultural constraints that influences his act of the car acquisition.

\section{Interpretations, Marketing Implications and Conclusion}

Our analysis supplied us key answers to questionings on the relation which undertakes the consumer with the product and on the contextual and socio-cultural constraints which govern this relation. Indeed, the acquisition of a personal car is not a harmless event of consumption because it joins in a process of life plan emanating from an identical production following trajectories in past, present and future and in perpetual dialogue with the discursive systems in the social, cultural and economic standing.

Consequently, the contemporary marketer before making a commitment in a marketing campaign (in the field of the automobile and or even in any other economic domain) is confronted to assume three contracts:

\section{- Understand the Consumer: know to whom he has to deal to encircle not only personality's features of his target public but also to understand the dynamism which governs the construction of their identities and its influence on their kinds of consumption. Indeed, from our analysis we noticed that the experience of consumption is an element mattering in the construction of a personal narrative on own sound lived for the consumer and that some brands participate actively in this construction, this is, through a process of alienation in the values emitted by the advertising speeches or through an own allocation of meanings subjected to psychological processes such as the memories, the attachment to a striking character ...}

The consumption can be also balanced according to the dichotomy between the will and the duty through which the social image and the notion of membership show themselves frequently during the course of a human life. In another shutter, we put the finger on the tactics and the guiles presses by the current consumer to resist and even divert the proliferation of the styles of consumption that knows our contemporary societies; it is an indefatigable quest towards the peculiarity through the individual creation of the lifestyle which challenges globally or partially the ruling models and the values in the social system.

- Encircle the Discursive Systems: It is a question of encircling the tensions that appear between these systems and the consumer. These conflicts show themselves in the new practices of consumption according to two manners: 
The first one consists in showing reluctance towards the structural systems pre-established by the communicational speeches. The second, which is more cooperative, consists in procreating a margin of operation to be able to model its process of consumption without knocking, neither the objective part of the identity that complies with the values emitted by the socio-cultural brands, nor the subjective part that emanates from a dynamic and negotiated construction. It is important to indicate also that if these systems are static and easy to encircle, the targets at which they aim are unstable and dynamic. In this way, it is better that the marketer concentrates his efforts on the detection of the tactical trajectories of his target then on the highlighted of all the economic, social, cultural, material constraints which mark the contemporary discursive systems.

- Model the Relation between Both with the Speech of His Brand: The consumer became more and more skillful in the reading of the advertising speeches. He acquired, henceforth, a growing capacity to decode them and to create associations except their purely communicational frames. This last suitability was acquired at by the consumer during his indefatigable quest towards the peculiarity through the otherness what will allow him, as we indicated it many times, to be able to create his own identical trajectories by negotiating with the established discursive systems. So, the work of the marketer will not, any more, consist in seizing the vast of these identical trajectories, but rather in conforming, in his turn, to this quest of peculiarity. This is by asserting a relatively stable singular vision through his communication speeches. He is also called to acquire the capacity to know how to anticipate any change in the discursive systems especially at the socio-cultural and economic levels which can affect, in a direct or indirect way his brand market. That will allow him to propose communicational speeches and offers which are more credible and more suggestive and especially in synchronization with the expectations of his target public. Finally, let's say that the marketer of today has to assimilate that the archaic notion of the alienated consumer does not exist anymore. This one was transformed into consom-actor who participates actively in the marketing work; he is even the vector catalyst of the new attempts of creative, methodological and practical extensions of this discipline.

\section{Conclusion}

This semiotic analysis allowed us to bring to light two revelations in the consumption process associated with the act of the personal car acquisition, by mixing the consumer's approach and the marketing approach in a socio-cultural context in perpetual transformation. The first revelation is concerning the method. This work articulates around a revolutionary methodology emanating from the fact that semiotics is the only science introduced in the marketing which abstains from subjecting to its rules and dogmas. Instead of considering the testimonies of our referees as texts to be analyzed according to qualitative and quantitative methods by revealing variables and correlations governing them to create a model. We opted in a more holistic vision by considering the relations rather than the objects and by considering the narratives of our interviewees as speeches producing a sense according to the context which they join.

The second revelation is relating to the triangular relation that we revealed between the production of the identity, the process of consumption and the sociocultural factors. Contrary to the marketing which focuses on the identical production in a bilateral relation between the consumer's cognitive process and the consummate product, our analysis allowed us to show that in fact this production crosses by three phases: The first one is purely subjective marked by strategies of demarcation, membership, alignment and peculiarity. The second is a semiotic Meta operation by giving a meaning to the sense 
already established for an object. And the third is embodied in a wider optics that of the life plan resulting from a perpetual negotiation between active subjects and discursive systems.

Nevertheless we have to admit that this method of analysis still presenting some gaps because it bases itself only on contextualisés speeches relating to a typical example of consumption of a well determined product and among which the interpretations and the implications emanate only from a purely semiotic point of view. So it can be generalized and recommended within the framework of a marketing strategy only when it is adjusted by a traditional study. Having said that, our work turns out then as a simple answer to the invitation to mobilize new experts in various domains such as psychology, sociology, anthropology, linguistics, and semiotics ..., to renew the traditional approaches of the Marketing discipline in the XXIth century (Barker, Nancarrow and Spackman, on 2001).

\section{References}

Alexandre Coutant, (2009). "Consommer Pour Exister Ou Consommer En Existant ? L'utilisation Des Marques Par Les Individus Comme Révélatrice Du Fonctionnement Identitaire, " Journée D'études Des Doctorants Du CIMEOS, Les Processus De Construction Identitaire En Sciences De l'Information Communication, Dijon.

Assassi, Isabelle; Bourgeon-Renault, Dominique (2010). Recherches En Marketing Des Activités Culturelles. Vuibert, 408 P. (53).

Bajoit, G. (2001). 'Une Jeunesse En Quete De Sens, Etre Soi Parmi Les Autres. Famille et Individualisation,' Tome 2, Dir. F. De Singly, Paris: L'Harmattan.

Barker, A. Nancarrow, C. \& Spackman, N. (2001). "Informed Eclecticism: A Research Paradigm for Twenty-First Century," International Journal of Market Research, 43, 1.
Barthes, R. (1957). Mythologies, Paris: Editions Du Seuil.

Bourdieu, P. (1979). La Distinction, Critiques Sociales Du Jugement, Paris : Editions De Minuit.

Brewer, M. B. (1991). "The Social Self: On Being the Same and Different at the Same Time," Personality and Social Psychology Bulletin.

Bruno Jarrosson (2004). 'Stratégie Sans Complexes, Collection : Stratégie et Management,' Dunod.

Certeau, M. (1980). L'invention Du Quotidien, Paris: U.G.E.

Christinsen, L. T., Askegaard, S. (2001). "Corporate Identity and Corporate Image Revisited - A Semiotic Perspective," European Journal of Marketing, Vol. 35, No. 3-4, Pp. 292-315.

Dano, F. (1994). 'Contribution De La Sémiotique a L'étude Des Attentes et Représentations Des Consommateurs A L'égard Du Packaging,' Thèse De Doctorat, Université Paris-Dauphine, Paris.

Dickinson, R. A. \& Carsky (2005). 'The Consumer as Economic Voter,' The Ethical Consumer, Éds. R. Harrison., T. Newholm et D. Shaw, UK: Sage Publications.

Douglas, M. \& Isherwood, B. (1979). 'The World of Goods: Towards and Anthropology of Consumption,' HarmondSworth Penguin.

Floch, J.- M. (1990). 'Sémiotique, Marketing et Communication,' Sous Les Signes, Les Stratégies, Paris : PUF.

Floch, J.- M. (2002). Sémiotique Marketing et Communication Sous Les Signes, Les Stratégies, P.U.F.

Fontanille, J. (2003). Sémiotique Du Discours, Limoges, Presses De l'Université De Limoges.

Fuat Firat, A. \& Venkatesh, A. (1993). "Postmodernity: The Age of Marketing," 
International Journal of Research in Marketing. Vol 29, Iss 1.

Fuat Firat, A. \& Venkatesh, A. (1995). "Liberatory Postmodernism and the Reenchantment of Consumption," Journal of Consumer Research. Vol 22.

Guy Parmentier \& Sylvie Rolland (2009). "Les Consommateurs Des Mondes Virtuels : Construction Identitaire et Expérience De Consommation Dans Second Life," Recherche et Applications En Marketing, Vol. 24, N³.

Hébert, L. (2006). "L'analyse Thymique," Dans Louis Hébert (Dir.), Signo [En Ligne], Rimouski (Québec), http. www.signosemio.com

Heilbrunn Benoit (2005). La Consommation Et Ses Sociologies, Paris, Armand Colin.

Hirschman, E. C. \& Holbrook, M. B. (1992). Postmodern Consumer Research: The Study of Consumption as Text, Newbury Park, CA, Sage.

Holt, D. B. (2002). "Why Do Brands Cause Trouble? A Dialectical Theory of Consumer Culture and Branding," Journal of Consumer Research, Vol 29, Num 1.

Jean-Claude Kaufmann \& François de Singly (2006). L'enquête et Ses Méthodes, / L'entretien Compréhensif, Paris, Armand Colin.

Jean-Jacques Boutaud (2007). "Du Sens, Des Sens. Sémiotique, Marketing et Communication En Terrain Sensible," Revue Sémiolinguistique Des Textes et Discours, SEMEN, Vol 23.

Kaufmann, J. C. (2004). L'invention De Soi. Une Théorie De L'identité, Paris, Armand Colin/SEJER.

Landowski, E. (1997). Présence De L’autre, Essais De Socio-Sémiotique II, Paris : PUF.

Lévi-Strauss, C. (1962). La Pensée Sauvage, Paris : Plon.
Longinos Matin, Salvador Ruiz \& Alicia Rubio (2009). "The Role of Identity Salience in the Effects of Corporate Social Responsibility on Consumer Behavior," Journal of Business Ethics, Vol 84 Num 1.

Mick, D. G., Burroughs, J. E., Hetzel, P. \& Brannen, M. Y. (2004). "Pursuing the Meaning of Meaning in the Commercial World: An International Review of Marketing and Consumer Research Founded on Semiotics," Semiotica, 152 (1/4). 1-74.

Nathalie Veg-Sala (2010). 'Marque et Communication: La Réconciliation Des Analyses Sémiotiques et Des Etudes Sur Les Perceptions Des Consommateurs,' Premières Journées De Recherche Sur Le Design De La Marque, Limoges, 30 Septembre et 1er Octobre.

Nathalie Veg-Sala \& Geerts, Angy (2012). "Gestion De La Cohérence Des Récits Des Marques De Luxe Sur Internet : Etude Sémiotique et Analyse Comparée Des Secteurs De La Maroquinerie et De La Joaillerie," Revue Française Du Marketing, A Paraître.

Nicole Evereart-Desmedt (1999). 'Benetton: Une Nouvelle Façon De Faire De La Publicité,' In Art \&Fact, N 18/, Mélange Philippe Minguet, Revue Des Historiens De L'art, Des Archéologues, Des Musicologues et Des Orientalistes De l'Université De Liège.

Ricoeur, P. (1990). Soi Même Comme Un Autre, Paris : Editions Seuil.

Semprini, A. (1992). 'Le Marketing De La Marque: Approche Sémiotique,' Editions Liaisons, Paris.

Solomon, O. (1988). "Semiotics and Marketing New Directions in Industrial Design Applications," International Journal of Research in Marketing, 4, Pp. 201-215.

Venkatesh, Alladi (1999). "Postmodernism Perspectives for Macromarketing: An Inquiry into the Global Information and Sign Economy," Journal of Macromarketing . Vol 19, Num 12. 


\section{Annex}

\section{The Guide of Interview}

- Can you describe me your car?

- How you chose it?

- How you bought it?

- If you can change it, will you choose the same brand? Why?

- Since when you have your own car?

- When I evoke the word transport, when means this word for you?

- Are you influenced by people who judge in the appearance?

- Do you often update your knowledge in the field of the automobile?

- How do you imagine your next personal car? 